\title{
Ambon City Local Government Medium-Term Development (RPJMD): Culture Transmission Through Panas Pela of Education as A Peacebuilding
}

\author{
Asyrul Fikri1 ${ }^{*}$, Anju Nofarof Hasudungan² \\ ${ }^{1}$ Department of History Education, Faculty of Teacher Training and Education, Universitas Riau \\ Bina Widya Campus KM. 12,5, Simpang Baru, Tampan, Pekanbaru City, Riau, 28291 \\ ${ }^{2}$ Senior High School 1 Rupat, Riau \\ Jl. Mesjid Kampung Jawa, Batupanjang, Rupat, Bengkalis, Riau, 28781
}

*Corresponding Author: Asyrul.fikri@lecturer.unri.ac.id

Pela Gandong local wisdom has played a significant role as a media for Ambon conflict resolution. The existence of dialogue and communication based on Pela Gandong culture can bring mutually battling parties to achieve peace. Therefore, the purpose of the study is to describe how SMPN 4 Salahutu Liang Central Maluku with 100\% Muslim students also, SMPN 9 Ambon City with 99\% of their Christian/Catholic students in implementing Panas Pela of Education as the transmission of Pela Gandong culture as an implementation of the Ambon City Regional Medium-term Development Plan (RPJMD). Panas Pela of education is an assemblage of students with different religions tore-warm the sibling relationship (Pela Gandong). This study uses descriptive qualitative research methods with a case study approach. Data collection is done by participatory observation, literature study, document analysis, and interviews. The results showed that the Panas Pela of Education activity on January 29, 2018, had succeeded in transmitting Pela Gandong culture to students to maintain peace. It can be seen by student's ability from both schools to blend in with one another without segregation and together celebrate the Panas Pela of Education. It is expected that the field of education implementing Panas Pela of Education sustainably. It will surely be successful because the local wisdom of the Pela Gandong has been integrated into the Ambon City Local Government Medium-term Development Plan (RPJMD).
\end{abstract}

Article

history :

Received: July 1, 2020

Revised: January 13, 2021

Accepted: March 23, 2021

Keywords:

local government medium-term development plan (RPJMD); education; panas pela; peace building

\section{INTRODUCTION}

Ambon Maluku conflict, which is the most prominent civil conflict after President Soeharto stepped down, can decrease its intensity with conflict resolution based on the local wisdom of Pela Gandong. The Ambon conflict peace agreement's climax can be 
realized through the Malino II Agreement on 12 February 2002. It surprised many parties. In the era of President Soeharto, local wisdom was passive, and after the end of this era, it became active. Especially as a medium for conflict resolution. This success was due to the Ambonese Maluku community succeeding in revitalizing the local wisdom of Pela Gandong amid the confusion of many parties on how to resolve the most significant civil conflict after the May 211998 Reform (Jati, 2013). The existence of dialogue and communication based on Pela Gandong culture can bring together conflicting parties to sit down together, stand up high together to find solutions, and achieve Ambon-Maluku peace.

Like the culture that continues to develop amid of community life. Pela Gandong is growing today by targeting other fields before and during the Ambon conflict that had never been done, namely, Panas Pela of Education. Besides, the need to continue to safeguard Ambon peace and the adequate local wisdom of Pela Gandong as a unifying force between Ambon-Maluku people who are Muslim and Christian. Pela and Gandong have become social institutions that have developed as an adhesive for social relations between one country and another, both Muslim and Christian. Therefore, Pela and Gandong are very functional in regulating the social interaction system for indigenous peoples that transcends various fields. Therefore, it is necessary to transmit Pela Gandong culture to Ambon-Maluku young generation through the Panas Pela of Education. Not only inheriting culture but also maintaining peace. Cultural transmission can be likened to the term cultural inheritance. Cultural transmission is the activity of sending or spreading messages from one generation to another about something that has become a habit and is difficult to change (Malatuny \& Ritiauw, 2018). So, Panas Pela of Education has a role as a new media for Pela Gandong to build peace among students today.

Panas Pela of Education is an activity for sending or spreading peace messages from generations experiencing conflict (teachers, principals) to students as generations who do not experience conflicts. Pela Gandong culture's importance to be passed on to students as an effort is not merely to preserve culture but also to entrust peace. Because, at present empirically, only Pela Gandong culture can unite Ambon-Maluku people who are Christians and Muslims in the concept of "basudara" (we are brothers)(Manuputty, Salampessy, Ali-Fauzi, \& Rafsadi, 2014).

It needs to be done considering that there are still peace vulnerabilities in Ambon-Maluku (Ansori et al., 2015). Besides that, peace is not just a goal; peace is a process itself. Often people forget and fall asleep after resolving conflicts, ignoring how to maintain and build peace. However, the conflict itself will continue to exist while there is still human lust in this world. Conflicts that have previously subsided have not subsided yet; nonetheless, there is fulfilling the peace gaps when there is a trigger, the conflict will re-occur. As prevention, students who are not survivors of the Ambon conflict must inherit Pela Gandong local wisdom values through Panas Pela of Education.The culture of Pela Gandong entered the school environment to get closer, contextualized, and become relevant to the current issue of peacebuilding. Students are not the only objects of peace but are subject to peace. Therefore, Ambon-Maluku students are the next generation to maintain and maintain peace which their ancestors have painstakingly realized.

31| Journal of Local Government Issues (LOGOS), 4 (1), March 2021, pp 30- 44 ISSN : 2620-8091 print | 2620-3812 online 
Panas Pela of Education means strengthening (panas) fraternal relations (pela) of Junior High School (SMPN) 9 Ambon City and SMPN 4 Salahutu Liang Central Maluku Regency, which the ancestors had previously built in the field of education. Panas Pela has done by holding ceremonies regularly. At such events, village partners gather in one village for about a week to celebrate their unity, accompanied by a renewal of oaths, parties, singing, and dancing. This agreement is made in a commitment that they cannot break.

During the oath ceremony, a mixture of soppi (tuak) and blood from each country'sleader's body will be drunk by the two leaders after weapons and others harp instruments are dipped or done by eating betelnut. Panas Pela of Education between SMPN 9 Ambon City and SMPN 4 Salahutu Liang was conducted on January 29, 2018, at SMPN 9 Ambon City with the address Wolter Monginsidi Lateri street Lateri Village, Baguala District, Ambon City, Maluku Province.

In Indonesia, the Regional Medium-Term Development Plan (RPJMD) study focuses more on implementation and evaluation. (Christiyanto, 2018) sees the bureaucracy's capacity, namely communication, resources, disposition, and organizational structure, which are vital in implementing the policies that have been announced in the RPJMD. In general, the RPJMD is highly dependent on implementation accountability (Febrian \& Handrisal, 2018). It is also confirmed by findings (Wahyuddin, 2017) regarding implementing the Education and Health Sector of Berau Regency in 2010-2015. The weak bureau cratic capacity will hinder the success of RPMJD programs, such as in the gap between the Plan and Implementation of the Pasuruan Regional Medium-Term Development Plan (RPJMD) 2013-2018 (Widiyanti, 2019), the Public Works Affairs Sector Program ofthe Anambas Islands Regency (Lestari, Rini, \& Dwiyanti, 2018). From the perspective of participation, (Yandra, 2016) found that in the preparation of the Pekanbaru City RPJMD, this participation had not effective because the community was not involved from the start in the RPJMD Formulation so that the community was stillseen as a subject in development. It is also very similar to Yogyakarta, where the local government is very dominan twith its technocratic approach (Kamim, Amal, \& Khandiq). This article does a further analysis by placing local wisdom as the capital for resolving the Ambon conflict. Pela Gendong, as local wisdom integrated in to the RPJMD, has provento be quite effective in building peace .

\section{METHOD}

This research was conducted with a descriptive qualitative research method with a plural case study approach in SMPN 9 Ambon City and SMPN 4 Salahutu Liang Central Maluku District. According to (Rahardjo, 2017), steps of case study research include selecting themes/topics/cases, reading of literature, formulation of focus and research problems, and data collection. Case study research data can be obtained from several techniques, such as interviews, participant observation, and documentation, refine the data. Next, data processing, data analysis, data analysis process, theoretical dialogue, triangulation of findings (confirmability), conclusions of research results, and research reports. These documents are records of past events, such as written notes, photos, or monumental works (World Peace Gong Ambon).

32| Journal of Local Government Issues (LOGOS), 4 (1), March 2021, pp 30- 44 ISSN : 2620-8091 print | 2620-3812 online 


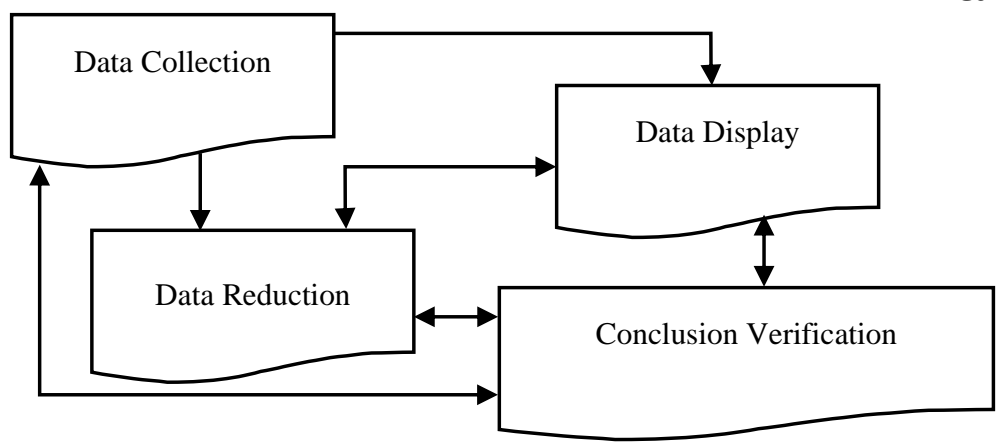

Figure 1. Interactive Analysis Model (Miles \& Huberman, 1992)

The interpretative analysis is generally seen in three stages: deconstruction, interpretation, and reconstruction. After preparing the data for analysis, these stages occur after the transcription of the interview or focus group and verification of the transcript by recording. Deconstruction refers to breaking down data into component parts to see what is included. It takes reading and rereading interviews or focus group transcripts and then splitting the data into categories or codes that describe the content. Interpretation follows deconstruction and refers to understanding and understanding the data encoded. It involves comparing data codes and types within and across transcripts and across variables considered necessary for research. Reconstruction refers to re-creating or repackaging main principles and themes that show the relationships and insights gained in the interpretation phase, explaining them more broadly given existing knowledge and theoretical perspectives. Reconstruction requires contextualization of findings, namely positioning and framing it in current theories, evidence, and practice.

This research problem is about social phenomena in Ambon City, Maluku, when local wisdom builds post-conflict peace. Therefore, a qualitative research method with a case study approach is the proper method to answer this research problem.

In this study, researchers are very interested in documents, such as Ambon City Local Government Medium-term Development Plan (RPJMD) document for the 20112016 and 2013 curriculum (Learning Implementation Plan, Syllabus, Semester, and Annual Program from Teachers); Archives regarding Pela Gandong. Local government policy regarding Pela Gandong in the field of education, and Social science education textbooks for SMPN 9 Ambon and SMPN 4 Salahutu Liang.

\section{RESULTS AND DISCUSSION}

\section{Pela Gandong Local Wisdom in The Ambon City Regional Medium-term Development Plan (RPJMD)}

The Local Government Medium-term Development Plan(RPJMD) from the Ambon City government has been well documented, clear, and contains how the local government strategy is to integrate local wisdom of Pela Gandong in education (Ambon, 2013). Following are the results of the researcher's analysis of the Local Government Medium-term Development Plan(RPJMD) document from the Ambon city government. Whereas, there are development issues that are directly related to peacebuilding after the 1999 Maluku Ambon conflict, namely: 
Tabel 1. The Linkage of Vision, Mission, Goals and Targets of the Ambon City Government's RPJMD with Local Wisdom of Pela Gandong

Vision: "An Advanced, Independent, Religious, Sustainable and Harmonious Community Based Ambon"

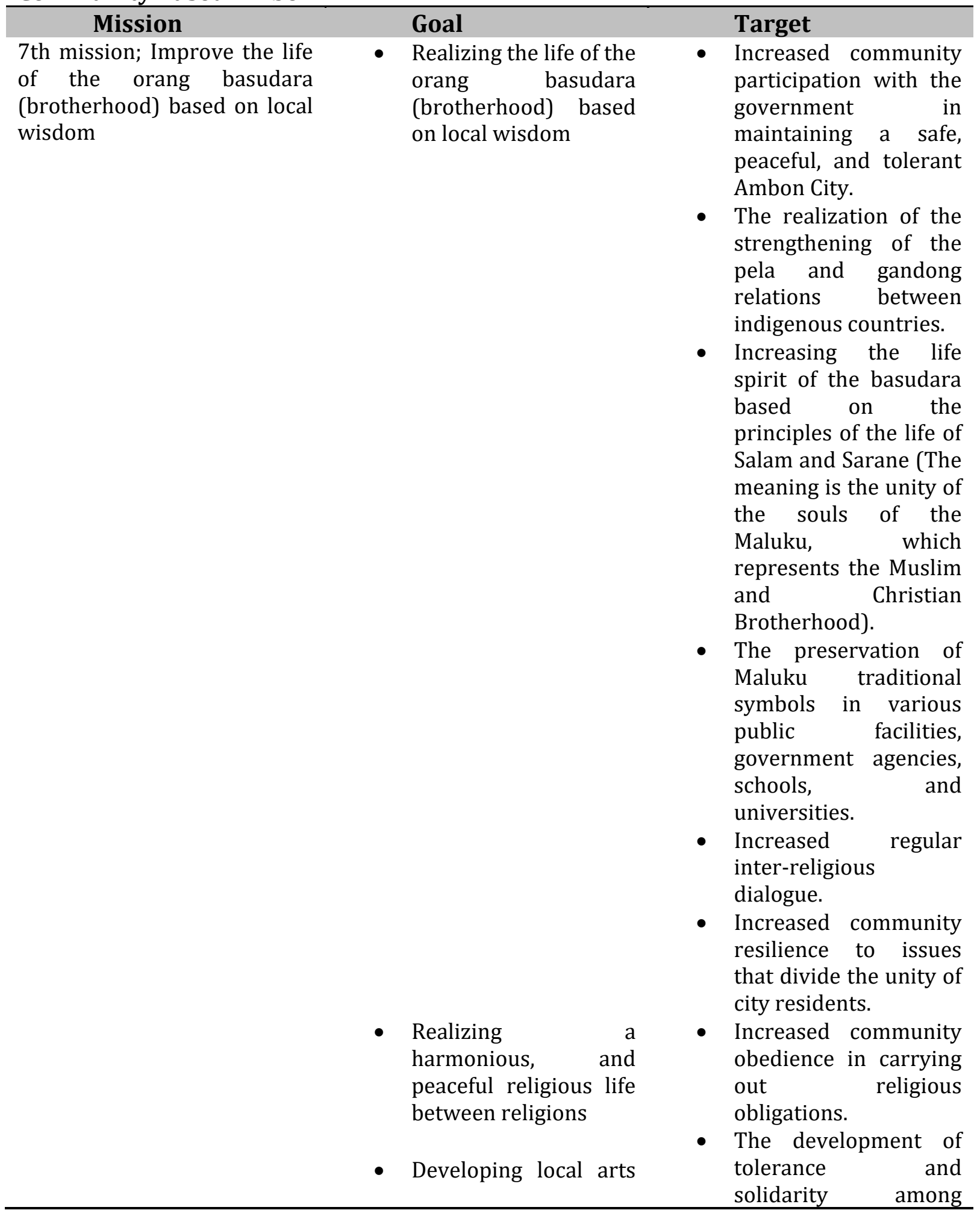


- The realization of community behavior based on norms, ethics, and religious values.

Source: (Ambon, 2013)

The purpose of preparing this RPJMD document is to formulate policy directions and development strategies for the next five years. The Local Government Medium-term Development Plan (RPJMD) emphasizes the importance of preparing the vision, mission, and schedule of the elected Regional Head in the objectives, targets, strategies, and development policies. It is essential to respond to community aspirations and agreement to measure the success of regional development in the next five years. In the context of this research, the integrated local wisdom of Pela Gandong in the Ambon City Government Local Government Medium-term Development Plan (RPJMD) as peacebuilding through cultural transmission.

\section{Implementation of Panas Pela of Education}

Peace is a perpetual work that never stops to be maintained and fought. Peace has no end but the process itself. One of the phases to continue to preserve and fight for peace is peacebuilding. Prevention of conflict in the post-conflict period is essentially the same as keeping the peace. The Ambon context is currently entering the peacebuilding phase. The current situation and condition of the Ambon City of Maluku are still peace vulnerabilities, significantly increasing political identity and populism after the 2014 and 2019 Presidential Elections of the Republic of Indonesia. In response to this and prevent conflicts from occurring in the past, various parties such as the United Nations Development Program (UNDP), together with national and local Maluku institutions such as Convey Indonesia, Center for Islamic and Community Studies Islamic State University (UIN)Jakarta, and (Ambon Reconciliation Mediation Center) ARMC Islamic State Religious Institutions (IAIN) Ambon hold Panas Pela of education. This is done to strengthen the Pela Gandong-based fraternity between SMPN 4 Salahutu and $100 \%$ of their Muslim students and SMPN 9 Ambon City with 99\% of their Christian/Catholic students.

This tradition can be said to be the development of the functions and scope of local wisdom of Pela Gandong. The success of Pela Gandong as an Ambon conflict resolution media is the initial thought that Pela Gandong can also be peacebuilding. Even dissertation research (Amirrachman, 2012) entitled Peace Education in the Moluccas, Indonesia: Between Global Models and Local Interests. This dissertation examines the impact of peace education projects supported by foreign institutions on selected schools in the conflict-affected Maluku province of Indonesia. This study reveals that the orientation of a culture-exclusive peace education curriculum - which favors one group over another - will not help overcome the strengths and social inequalities rooted in Maluku society. This dissertation analyzes conflict-affected societies where imbalances of power between religious and ethnic groups can still be

35| Journal of Local Government Issues (LOGOS), 4 (1), March 2021, pp 30- 44 ISSN : 2620-8091 print | 2620-3812 online 
found. Religious and ethnic sentiments still undermine competition for power and influence between them - further exacerbated by traditional beliefs, legitimizing religion.

Panas Pela is renewing Pela with traditional rituals about sibling relations in many traditional villages in Ambon-Lease and several villages on Ceram Island, central Maluku. Rituals are always interpreted as symbols of brotherhood, social integration, and beliefs(Tapotubun, 2018). Pela is derived from the local language from the word 'pelau', which means' brother. Terminologically interpreted as a bond of friendship or brotherhood that is connected between all indigenous peoples of the two or more countries. Pela hasbeen formed and established by their ancestors in particular circumstances and includes the rights and obligations for the parties in it (Wakano, 2019). Panas Pela of Education is a tradition whose purpose is to warm/strengthen the relationship of brotherhood that has been built by the ancestors / previous generations in the field of education. State Junior High School (SMPN) 4 Salahutu Liang, Central Maluku Regency and SMPN 9 Ambon City have held a fraternity since 2013 (Harmusial, 2019).

Education is considered the suitable media, and young people (students) are considered potential cadres to accept the values of peace and fraternity from the local wisdom of Pela Gandong. According to Rev. Jack Manuputty and teacher (Ustadz) Abidin Wakano, young people can be a cadre of peaceful provocateurs (Tuwanakotta, 2017). Therefore, the Panas Pela of Education conducted by the two schools is a form of Pela Gandong culture transmission.

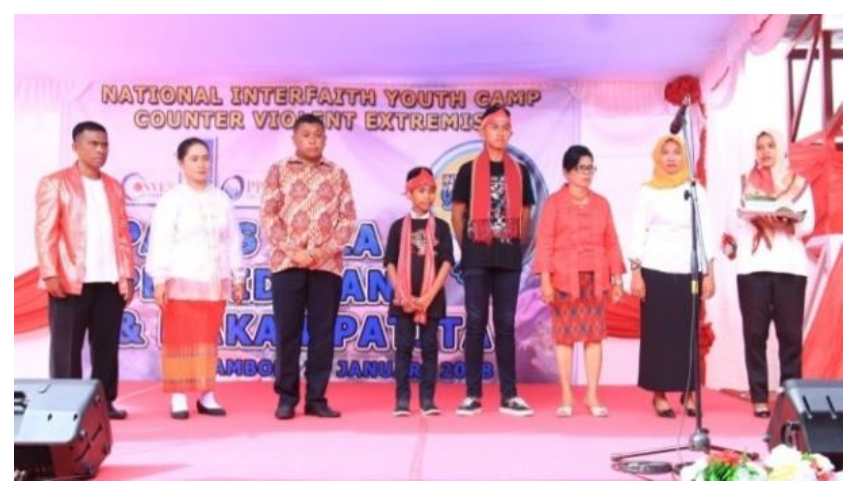

Figure 2. Panas Pela of Education by both schools (personal documentation)

Panas Pela of Education as an effort to build peace in post-conflict Ambon is carried out as follows: the transformation of Pela values continues between State Junior High School (SMPN) 9 Ambon City where 99\% of the students and teachers are Christian, and SMPN 4 Salahutu Liang, Central Maluku Regency, 100\% of the students, and the teachers are Muslim. Various methods are carried out, such as teacher exchanges and activities such as scouting activities, Christmas, iftar, camping, Sports and Arts Week Competition (Porseni), and student council activities. Both schools are also part of making the 2013 Provocateurs of Peace film as a form of peace campaign and the value of multicultural diversity. According to (Onyenankeya, Onyenankeya, \& Osunkunle, 2017), the film is seen as a powerful vehicle for transmitting or mediating culture. The climax, almost every year, these two schools do a 'reuni' which in 
traditional terms is called Panas Pela (Figure 2). The Panas Pela was marked by eating betel nut by the Principal of SMPN 9 Ambon E. Harmusial accompanied by the Chairperson of OSIS Jack Deaand the Head of SMPN 4 Salahutu Liang, Hilia Pary, and the Chairperson of Student Organization (OSIS), Dimara Dinasti Laga. The good relations between students and teachers of the two schools went harmoniously and increasingly harmonious.

\section{Transmission of Culture Through Panas Pela of Education as A Peacebuilding}

Education is a means of cultural inheritance (Suastra, 2005). It meansculture is society's identity (Rathje, 2009) so that its existence must be passed on to the next generation. Cultural transmission through the Panas Pela of Education has played a role in building post-conflict peace in Ambon. So, it is hoped that peace will continue to be maintained and prevent conflicts from recurring. In essence, the Ambon conflict resolution continues to this day. Like peace, the work that is never finished. However, even when it stopped, conflict immediately occurs, especially in Ambon, Maluku, which still has peace vulnerabilities. Educational institutions that bring together children of the nation from various characters offered intellectual enlightenment and strengthened togetherness culture. Educational institutions at all levels are the best place for effective conflict resolution because they are possible for a long time to experience, discuss, reflect, and with the guidance of teachers to manage conflict (Ahmad, 2009). Furthermore Tambunan in (Ahmad, 2009) explained that educational institutions have a very strategic role in building a peaceful culture. Therefore, educational institutions need to be designed as peacebuilding institutions that provide various educational programs that foster much experience in building peace and conflict management.

In his interview with the Governor of Maluku at the time, Said Assagaff said:

"It must be admitted that the development of increasingly modern times often brings tendencies and forgets cultural values, the customs of the regions inherited from our ancestors since long ago. Pela culture is one of the social systems which is the social bond of two countries or the oath of promise, bound by our ancestors to maintain the kinship with one another. He continued, with the Panas Pela of Education from these two schools will be an example to be copied from schools and other educational institutions in order to improve tolerance relations and be able to implement in culture. It is expected that this Panas Pela of Education can provide a positive value on the quality of quality education for our students in these two institutions" (Interview Source on January 29, 2018).

Empirical conflict resolution is carried out in four stages (Astri, 2011), namely: Stage I, looking for de-escalation of conflict. At this stage, the conflicts that occur are generally characterized by armed conflicts, so the conflict resolution process must be carried out in collaboration with military orientations. The conflict resolution process can be started if indications start that the parties to the conflict will reduce conflict escalation. In reality, at present, the parties to the conflict are more open to accepting negotiations to reduce the burden of increased costs of violence.

37| Journal of Local Government Issues (LOGOS), 4 (1), March 2021, pp 30- 44 ISSN : 2620-8091 print | 2620-3812 online 
Stage II, humanitarian intervention and political negotiations when the deescalation of the conflict has occurred, the second stage of the conflict resolution process can begin together with implementing humanitarian interventions to ease the burden of suffering victims of the conflict (Crocker, Hampson, \& Aall, 1997). This principle is one of the fundamental changes of humanitarian intervention in the $90 \mathrm{~s}$, requires humanitarian intervention to no more symbolic move in the periphery environment of armed conflict but must approach the war's central point. It is based on the fact that civilian casualties and the most significant potential human rights violations are at the center of the war, and at that location, no one can carry out rescue operations other than third parties. Humanitarian intervention can be carried out in conjunction with efforts to open up opportunities for inter-party negotiations.

Stage III, problem-solving approach. The third stage of the conflict resolution process is problem solving which has a social orientation. This stage is directed to create a conducive condition for the antagonists to transform a specific conflict resolution (Jabri, 1996). Conflict transformation can be successful if the two conflicting groups can reach a mutual understanding of how to explore alternatives to resolving conflicts that each community can directly work out. Alternatives to the conflict solution can be explored if there is a conflict resolution institution that seeks to find the fundamental causes of a conflict. For Burton (Hadi, 2007) these fundamental causes can only be found in the conflict is analyzed in the context of the total environment.

Stage IV, peace-building The fourth stage is peace-building which includes the transition phase, the reconciliation stage, and the consolidation stage. This stage is the heaviest and will take the longest time because it has a structural and cultural orientation. In this section, the researchers' study; describe how the Panas Pela of Education is an effort to build peace after the Ambon conflict. Reconciliation needs to be done if the potential most profound conflict experienced by a community is the community's fragility of social cohesion due to various structural violence that occurs in the community's historical dynamics. While the consolidation stage requires relevant actors to continue to intervene in peace with social structures with two main objectives, namely to prevent the recurrence of conflicts involving armed violence and to construct a lasting peace process that the parties can carry out to the conflict (Miall, Ramsbotham, \& Woodhouse, 2002). Criticism from (Clapham, 1998) refers to the international community's increasing role in global conflict resolution. After the Cold War, the collapse of the Soviet Union marked the emergence of new actors in the international system. The principle of territorial integrity and non-intervention of sovereign states has also shifted to the standardization of international conflict resolution mechanisms dominated by US liberalism. This condition gave rise to a new conflict resolution model, namely mediation with a ceasefire strategy that paused to carry out negotiations. According to Clapham's criticism, this approach tends to be technical and excludes political agreement from the parties' commitment. Besides, there is no guarantee that the mediator can be completely neutral.

In Indonesia, the province of Aceh was the first turbulent and conflicted region to receive United Nations Children's Fund (UNICEF) support in the form of peace education in January 2001. UNICEF also held activities related to peace education in Maluku. Another international body is the UNDP, founded in 1965 when the General

38| Journal of Local Government Issues (LOGOS), 4 (1), March 2021, pp 30- 44 ISSN : 2620-8091 print | 2620-3812 online 
Assembly combined the Expanded Program of Technical Assistance (EPTA) and the Special Fund. UNDP helps developing countries to attract and utilize aid, which is claimed to be an effective way. UNDP, together with Peace Through Development (PTD). The Japan International Cooperation Agency (JICA) established the Community Empowerment Eduacation Orang Basudara (CEP-POB), which regards Muslims and Christians as brothers and sisters also involved 24 junior high schools from Leihitu and Baguala on Ambon Island in 2006 and 2007.

Besides, UNICEF and UNDP launched a peace education program called the Pendidikan Orang Basudara Curriculum in 2006 and the School of Reconciliation from 2004 to 2005, also on Ambon Island, as an effort to integrate "a culture of peace framed by the strengths of the Central Maluku local tradition in the teaching-learning process" (Amirrachman, 2012) and increasing awareness about the potential contained in religious and cultured pluralism. John Paul Lederach (1995) said that in the transformation of conflicts, the importance of empowering indigenous peoples must actively dream, include, respect, and promote human and cultural resources from within the given arrangements (Woodhouse, 2000). From that point on, the value of local wisdom that plays a role in managing social conflict in society is an essential aspect in bringing up communication with a non-Western perspective namely the Asian Perspective (Widiyowati, Kriyantono, \& Prasetyo, 2018).

Research from (Jafar, 2018) revealed that the local wisdom approach was used to eliminate the politicization of customary law so that the potential for conflict did not reappear, and the family approach was to erase judgment, while government support served to accommodate the demands of both parties. By using the tradition of regional equality, this conflict can be resolved or by approaching positive peace as the institutionalization of values that can influence both parties' behavior to anticipate new conflicts. Therefore, peacebuilding is needed with a locally based approach and can unite the two warring parties, such as the Panas Pela of Education in Ambon-Maluku. The stages of the Peace Building of Panas Pela of Education at State Junior High School (SMPN) 9 Ambon City and SMPN 4 Salahutu Liang, Central Maluku Regency, are as follows:

\section{Transition Stage}

After the Ambon conflict, the impact of Segregation was getting worse, also affects education. Regarding the history of Pela Gandong, local wisdom by transmitting to the field of education to be called the Panas Pela of Education. Henny Liklitiwatil, Teacher of State Junior High School (SMPN) 9 Ambon City, explains in detail as follows:

"The 1999 conflict was already mixed with the issue of Inter-Ethnic Race (SARA) Ethnic Religion. Therefore, when the post-conflict reconciliation occurs, place of residence (segregation). The Muslim community lives in a Muslim area; the Christian community lives in a Christian site. It also influences in the world of education. Muslim also means attending schools in Muslim areas as well as Christians so that there is no encounter between Muslims and Christians. The conflict continued in 2013 there were teachers in Ambon and Central Maluku who were called to participate in education, training on how teachers became agents of peace because teachers were one of the main actors in the role of

39| Journal of Local Government Issues (LOGOS), 4 (1), March 2021, pp 30- 44 ISSN : 2620-8091 print | 2620-3812 online 
bringing about peace in the field of education" (Source of the interview on November 13, 2019).

Then how is the education sector chosen to be a means to build peace based on local wisdom. Following is an explanation from SMPN 4 Salahutu Liang Teacher in Central Maluku District, Muhammad Yusuf:

" This Pela we have been up for a long time, the base is local because we present a lot of local cultural wisdom that Pela do not have to be outside, it does not have to be in the community; it must be in school too.We build the Pela Character; we enter education so that they have a motivated spirit for generating togetherness in Pela, in social relations because it is essentialfor the development of their lives. So that it is not separate and different " (Source of the interview on November 8, 2019).

\section{Reconciliation Stage}

Henny Liklitiwatil explained the reconciliation process between teachers of the two schools pioneered in 2013. The following is an explanation:

"ARMC Foundation (Ambon Reconciliation Mediation Center) whose director MrAbidinWakano. The teachers are called to participate in the training activities, the Christian teachers live in Muslim areas and Muslim teachers live in Christian sites. After all that is done, we make a follow-up activity when these teachers are asked not to theorize but to practice " (Source of the interview on November 13, 2019).

Muhammad Yusuf gave an example of Pela-based reconciliation between SMPN 4 Salahutu Liang and SMPN 9 Ambon City. The following description:

"If multicultural activities are inevitable, if we are here, the majority of students are Muslims. However, multicultural activities, information, and material still exist because we are public schools; there are also non-Muslim teachers. There are three non-Muslim teachers, but for all Muslim students. If we are at SMPN 9 Ambon City, we have 99\% Christian students, and there are about 30 Muslim students and their religious teachers from here; we take from the concept of Pela with SMPN 4 Liang. We teach Muslim students, we are ready for particular subjects of religion; we also often exchange information "(interview source on November 8, 2019).

The explanation from Muhammad Yusuf can be concluded that the Pela-based reconciliation process is no longer targeting teachers but students and the learning process.

\section{Consolidation Stage}

This stage aims to strengthen the fraternal relationship (Pela) established in 2013 between SMPN 4 Salahutu Liang and SMPN 9 Ambon City. The consolidation was done on Monday, January 29, 2018, the two schools implemented Panas Pela of Education. Presenting various cultural attractions by students from both schools, such as dance, song, and poetry, leads and encourages students to love one another despite

40| Journal of Local Government Issues (LOGOS), 4 (1), March 2021, pp 30- 44 ISSN : 2620-8091 print | 2620-3812 online 
the different religions. The series of cultural attractions (Figure 3) displayed by students of both schools can be interpreted as cultural transmission. Besides, teachers can also become cultural transmitters (Astuti, 2016).

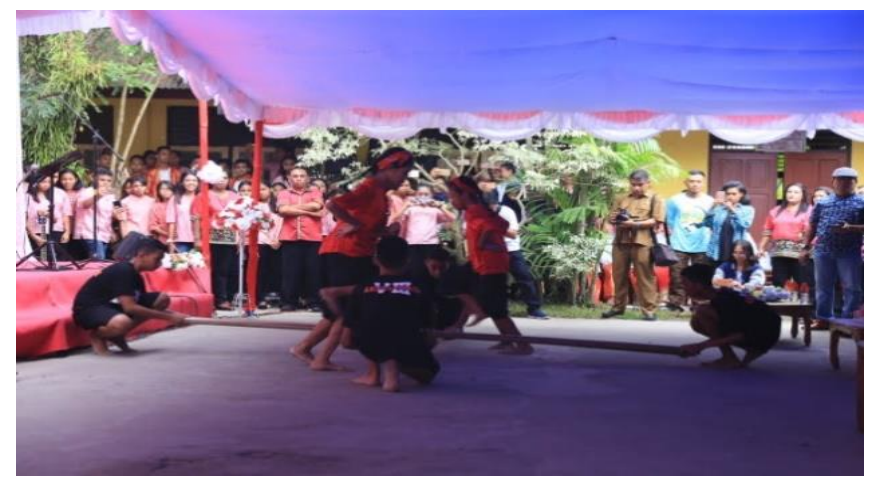

Figure 3. Students from Both Schools Perform Regional Dance (personal documentation)

\section{CONCLUSION}

The Ambon conflict resolution, which began on 12 February 2002 through the Malino II Agreement, continues to this day and currently in stage four, Peace-building. Ambon conflict resolution based on local wisdom of Pela Gandong continues to be maintained even transmitted to students at SMPN 9 Ambon City and SMPN 4 Salahutu Liang Central Maluku Regency. It is possible because of the integration of Pela gandong local wisdom in the Ambon City Government Local Government Medium-term Development Plan (RPJMD). The aim is to remember the potential for conflict in Ambon City Maluku. It can be seen from the still segregation between Christianity and Islam's adherents, the rise in identity politics and populism during the 2014 and 2019 Presidential and Vice-Presidential Elections. Therefore, various parties began transmitting Pela Gandong local wisdom into a Panas Pela of Education, which started in 2013 until now. Among them is the Ambon city government, which has integrated the local knowledge of the local Pela Gandong in the Local Government Medium-term Development Plan (RPJMD). This effort was made for Peace-building. Cultural transmission through Panas Pela of Education has succeeded in building peace in Ambon-Maluku today. Pana Pela of Education's role is carried out using teacher exchanges and joint activities such as scout activities, camping, Christmas, Iftar, Sports and Arts Week Competition (Porseni), and student council activities. The two schools were also part of the 2013 Peace Provocator film making as a form of peace campaign and the value of multicultural diversity.

\section{REFERENCES}

Ahmad, A. (2009). Mengembangkan Budaya Damai di Sekolah Melalui Manajemen Kelas Yang Demokratis Berbasis Nilai-Nilai Keislaman. HUNAFA: Jurnal Studia Islamika, 6(2), 139-152. https://doi.org/10.24239/jsi.v6i2.127.139-152

Ambon, P. K. (2013). RPJMD 2011-2016, https://ambon.go.id/rpjmd-2011-2016/. Ambon. 
Amirrachman, R. (2012). Peace Education in the Moluccas, Indonesia: Between Global Models And Local Interests. UvA-DARE (Digital Academic Repository)(nd). Dissertation: University of Amsterdam

Ansori, M. H., Putra, R. P. A., Efendi, J., Peranto, S., Sukandar, R., Cholid, S., . . Hutagalung, V. (2015). Post-Conflict Democracy, Violence, and Peace-Building in Aceh and Maluku. Jakarta: The Habibie Center.

Astri, H. (2011). Penyelesaian konflik sosial melalui penguatan kearifan lokal. Aspirasi: Jurnal Masalah-masalah Sosial, 2(2), 151-162. https://doi.org/10.46807/aspirasi.v2i2.439

Astuti, S. D. (2016). Transmisi Budaya dan Kearifan Lokal pada Pendidikan Islam Anak Usia Dini. Jurnal penelitian, 13 (1) 1-14. https://doi.org/10.28918/jupe.v13i1.1190

Christiyanto, F. (2019). Implementasi Program Rencana Pembangunan Jangka Menengah Daerah (RPJMD) Kabupaten Kutai Barat Tahun 2011-2015. Jurnal Administrative Reform (JAR), 6(2), 93-101. http://dx.doi.org/10.52239/jar.v6i2.1903

Clapham, C. (1998). Rwanda: the Perils of Peacemaking. Journal of Peace Research, 35(2), 193-210. Retrieved March 23, 2021, from http://www.jstor.org/stable/425520

Crocker, C. A., Hampson, F. O., \& Aall, P. (1997). Managing Global Chaos: Sources of the Responses to International Conflict. Long Range Planning, 30 (4).

Febrian, R. A., \& Handrisal, H. (2018). Akuntabilitas Pencapaian Visi, Misi, Dan Program Kepala Daerah Dan Wakil Kepala Daerah Terpilih (Studi Bidang Kehutanan Pada RPJMD 2014-2019 Provinsi Riau). KEMUDI: Jurnal Ilmu Pemerintahan, 3(1), 1-35. Retrieved from https://ojs.umrah.ac.id/index.php/kemudi/article/view/764

Hadi, S. (2007). Disintegrasi Pasca Orde Baru: Negara, Konflik Lokal, dan Dinamika Internasional. Sleman: Yayasan Obor Indonesia.

Harmusial, L. D. (2019). Interview witfh head of SMPN 9 Kota Ambon.

Jabri, V. (1996). Discourses on Violence: Conflict Analysis Reconsidered. Manchester: Manchester University Press.

Jafar, M. (2018). Conflict Resolution of Regional Head Election (PILKADA) Buru Selatan District in 2015. Journal of Local Government Issues (LOGOS), 1(2), 152-177. https://doi.org/10.22219/logos.Vol1.No2.152-177

Jati, W. R. (2013). Kearifan Lokal Sebagai Resolusi Konflik Keagamaan. Walisongo: Jurnal Penelitian Sosial Keagamaan, 21(2), 393-416. https://doi.org/10.21580/ws.21.2.251

Kamim, A. B. M., Amal, I., \& Khandiq, M. R. Aspek Politik Perencanaan Pembangunan RPJMD Daerah Istimewa Yogyakarta 2017-2022. Jurnal Wacana Kinerja 21 (2), 55-75.

Lestari, L., Rini, D. M., \& Dwiyanti, N. (2018). Evaluasi Pelaksanaan Rencana Pembangunan Jangka Menengah Daerah (RPJMD) Bidang Urusan Pekerjaan Umum Kabupaten Kepulauan Anambas, Provinsi Kepulauan Riau. Jurnal Trias Politika, 2(2), 203-215. https://doi.org/10.33373/jtp.v2i2.1469 
Malatuny, Y. G., \& Ritiauw, S. P. (2018). Eksistensi Pela Gandong Sebagai Civic Culture Dalam Menjaga Harmonisasi Masyarakat di Maluku. Sosio Didaktika: Social Science Education Journal, 5 (2), 35-46. https://doi.org/10.15408/sd.v5i2.10554

Manuputty, J., Salampessy, Z., Ali-Fauzi, I., \& Rafsadi, I. (2014). Carita orang basudara: Kisah-kisah perdamaian dari Maluku. Maluku: Lembaga Antar Iman Maluku.

Miall, H., Ramsbotham, O., \& Woodhouse, T. (2002). Resolusi Damai Konflik Kontemporer. Jakarta: PT Raja Grafindo.

Miles, M. B., \& Huberman, A. M. (1992). Analisa Data Kualitatif (edisi 1). Jakarta: Penerbit Universitas Indonesia.

Onyenankeya, O., Onyenankeya, K., \& Osunkunle, O. (2017). The Persuasive Influence of Nollywood Film in Cultural Transmission: Negotiating Nigerian Culture in A South African Environment. Journal of Intercultural CommunIcatIon Research, 46(4), 297-313.

Rahardjo, M. (2017). Studi Kasus Dalam Penelitian Kualitatif: Konsep dan Prosedurnya. Research Repository Universitas Islam Maulana Ibrahim Malang. http://repository.uin-malang.ac.id/1104/1/Studi-kasus-dalam-penelitiankualitatif.pdf

Rathje, S. (2009). The Definition of Culture: An Application-Oriented Overhaul. Interculture Journal, 35. https://ssrn.com/abstract=1533439

Suastra, I. W. (2005). Merekonstruksi Sains Asli (Indigenous Science) Dalam Rangka Mengembangkan Pendidikan Sains Berbasis Budaya Lokal di Sekolah: Studi Etnosains Pada Masyarakat Penglipuran Bali. Tesis: Universitas Pendidikan Indonesia.

Tapotubun, H. (2019). "Panas pela: Unchanged Ritual and Renewal the Meaning". International Journal of Peace adn Development Studies.

Tuwanakotta, F. (2017). Media Sosial Sebagai Ruang Publik Komunitas Muda-Mudi Dalam Mengantisipasi Ancaman Konflik Ambon Akibat Segregasi. Tesis: Universitas Gadjah Mada.

Wahyuddin, M. (2017). Evaluasi Pelaksanaan Rencana Pembangunan Jangka Menengah Daerah (RPJMD) Kabupaten Berau Tahun 2010-2015 Bidang Pendidikan Dan Bidang Kesehatan. Jurnal Paradigma (JP), 5(1), 1-10. http://dx.doi.org/10.52239/jp.v5i1.423

Wakano, A. (2019). Nilai-nilai Pendidikan Multikultural dalam Kearifan Lokal Masyarakat Maluku. al-Iltizam: Jurnal Pendidikan Agama Islam, 4(2), 26-43. http://dx.doi.org/10.33477/alt.v4i2.1006

Widiyanti, J. H. (2019). Kesejangan antara Rencana dan Implementasi Rencana Pembangunan Jangka Menengah Daerah (RPJMD) Kabupaten Pasuruan Tahun 2013-2018. Jurnal Ilmiah Administrasi Publik, 5(3), 432-439. https://doi.org/10.21776/ub.jiap.2019.005.03.21

Widiyowati, E., Kriyantono, R., \& Prasetyo, B. D. (2018). Model Manajemen Konflik Berbasis Kearifan Lokal: Konflik Perguruan Pencak Silat di Madiun-Jawa Timur. Komunikator, 10(1), 34-47. https://doi.org/10.18196/jkm.101004

43| Journal of Local Government Issues (LOGOS), 4 (1), March 2021, pp 30- 44 ISSN : 2620-8091 print | 2620-3812 online 
Woodhouse, T. (2000). Conflict Resolution and Peacekeeping: Critiques and Responses. International Peacekeeping, 7(1), 8-26. https://www.researchgate.net/deref/http\%3A\%2F\%2Fdx.doi.org\%2F10.1080 \%2F13533310008413816

Yandra, A. (2016). Partisipasi Masyarakat dalam Penyusunan Rencana Pembangunan Jangka Menengah Daerah (RPJMD) Kota Pekanbaru 2012-2017. PUBLIKA: Jurnal Ilmu Administrasi Publik, 2(1), 48-58. 